\section{Erasing the Material Base of Occupy Wall Street: When Soft Means Fail}

Christopher Leary

Queensborough Community College, Department of English, U.S.A
KOME - An International Journal of Pure Communication Inquiry Volume 3 Issue 2, p. 44-63.

(C) The Author(s) 2015

Reprints and Permission: kome@komejournal.com

Published by the Hungarian Communication

Studies Association

DOI: 10.17646/KOME.2015.24

\begin{abstract}
When Occupy Wall Street proved able to reach mass circulation in 2011, it registered as a threat to the status quo in the United States, where corporate entities with close relation to government normally control the flow of discourse. The Occupy encampments, therefore, were intolerable, not merely an annoyance that could be ignored or ridiculed. Once Occupy's anti-corporate rhetoric had spread widely, the mainstream media took steps to derail the mass appeal of Occupy's oppositional discourse through accusations of incoherence and indecency. However, such "soft" means of organizing consent from the public were very weak in 2011 because of the 2008 economic collapse which had been provoked by Wall Street. With instruments of soft persuasion weak, the dominant group turned to instruments of hard persuasion arrests, harassments, beatings, random grabs, and finally the orchestrated assault carried out on November $15^{\text {th }}$, an operation that saw the media censored and sequestered, at night, in the dark, with no filmed images, and all subway stations and street access blocked.
\end{abstract}

Keywords: surveillance, information control, policing, citizen movements, Occupy Wall Street

\title{
Introduction
}

Norman Fairclough, a leading theorist of critical discourse analysis, states in his 2006 book Language and Globalization that discourse has only a limited ability to shape the "actual" world. The "real" processes of globalization, he argues, are too complex "to be fully controlled by any human intervention" (24). However, to the extent that real processes can be influenced, "various groups of people develop strategies to try to regulate, direct and control elements of these real processes" (2006: 24). In the U.S., financial elites control the corporate media (Bagdikian 2004; Croteau and Hoynes 1994) so pro-business discourses are usually the ones most able to inflect the trajectory of globalization. Opposition groups and individuals 
regularly offer alternatives to dominant pro-business narratives but mass circulation of those alternative narratives is rare. The question of mass circulation is a crucial one, because, as Fairclough points out, "The mere existence of alternative discourses means little. It is only those which pass through the mechanisms and processes of selection and retention that can contribute to social (re)construction" (2006: 24). In the U.S., oppositional rhetoric thrives in the margins, but it rarely reaches the level of circulation that would yield a meaningful contribution to social (re)construction.

However, in the aftermath of the 2008 financial crisis, after an unpopular trillion-dollar bailout of private banks with public taxes, pro-business narratives lost their capacity to persuasively explain events, which created an opportunity for radical critique of finance to gain legitimacy. In 2011, Occupy Wall Street used an illegal encampment in a Lower Manhattan park to exploit this opening, developing a functioning delivery system for mass circulation and mass appeal. Through Occupy's improvised apparatus, mass anger at the vast power and wealth of Wall Street consolidated and circulated heavily in the mass media for several months.

Long-term, successful mass communications by an oppositional group in the United States interferes by definition with the monopoly on mass communications held by financial elites with close ties to government elites. This article, then, examines efforts to reassert control of mass representation and public discourse in the face of a non-violent movement's challenge to the dominant media's pro-business narratives. Fieldnotes from my participant-observation in Occupy Wall Street, as well as news reports and published meeting minutes, provide the raw data for my study, which describes the formidable repertoire of tools that elites turned to in order to shore up a public transcript that was severely tested from below.

Authorities in a constitutional republic (such as the U.S.) prefer to keep physical violence limited, but in this case, discursive tools alone proved incapable of keeping radical rhetoric from breaking through to mass audiences, requiring the use of paramilitary force in order to push radical critique of finance back to the margins. The turn to instruments of hard persuasion was most evident in the New York Police Department's orchestrated assault on November $15^{\text {th }}, 2011$, an operation that saw the media censored and sequestered, at night, in the dark, with no filmed images, and all subway stations and street access blocked. Reporters with press passes were forced to leave Zuccotti Park and placed in a "free-press zone" (Gillham, Edwards, and Noakes 2013) where they were unable to witness or collect video on the confrontation.

If these writers had been able to witness the police attack, they would have seen that a massive force of police in riot gear descended on the encampment, unannounced after midnight, backed up by sanitation crews dumping the mountain of debris left in the wake of the police sweep. Police arrested over 200 people, including a few journalists. Officers in riot gear beat campers with batons, tore apart their built environment, littered the floor with their books, tents, medical supplies, food, religious artifacts, and personal property.

The operation started right after midnight, when police trucks took positions along Zuccotti Park's perimeter. Officers set up a perimeter with a one-block radius in order to keep supporters away and they arrested 28 people who tried to bust through. At 1 a.m., police turned on the klieg lights and loudspeakers; officers spread leaflets ordering demonstrators to leave. Those who did not leave by 1:45 a.m. were dragged out. (Baker and Goldstein 2011) Sanitation workers followed, picking up any belongings left behind. It took 150 sanitation workers from all five boroughs to haul out 26 truckloads of clothes, tents, musical instruments, books, sleeping bags, and electronics (Gregoran, Sutherland, and Fredericks 2011). At 3:30 a.m., the last group of demonstrators locked arms in the Occupy Kitchen, refusing to let go of the park. Two demonstrators chained themselves to trees. Police beat this 
core group with batons in order to get them to delink, and then arrested them. By 4:15 a.m., the park was clear. (Baker and Goldstein 2011)

As I show in this article, authorities turned to paramilitary force only after soft, discursive tools proved ineffective. The first strategy for remarginalizing Occupy - ignoring the demonstrations - did not succeed, primarily because Occupy had leveraged its own communication systems to circulate its anti-corporate message to a wider and wider audience. The second strategy - tarring Occupy as unworthy of association - had only limited success because Occupy's message had mass legitimacy after the financial collapse of 2008.

Figure 1: In the heart of New York's Financial District, a marginalized narrative reached thousands of daily visitors. All photographs by author.

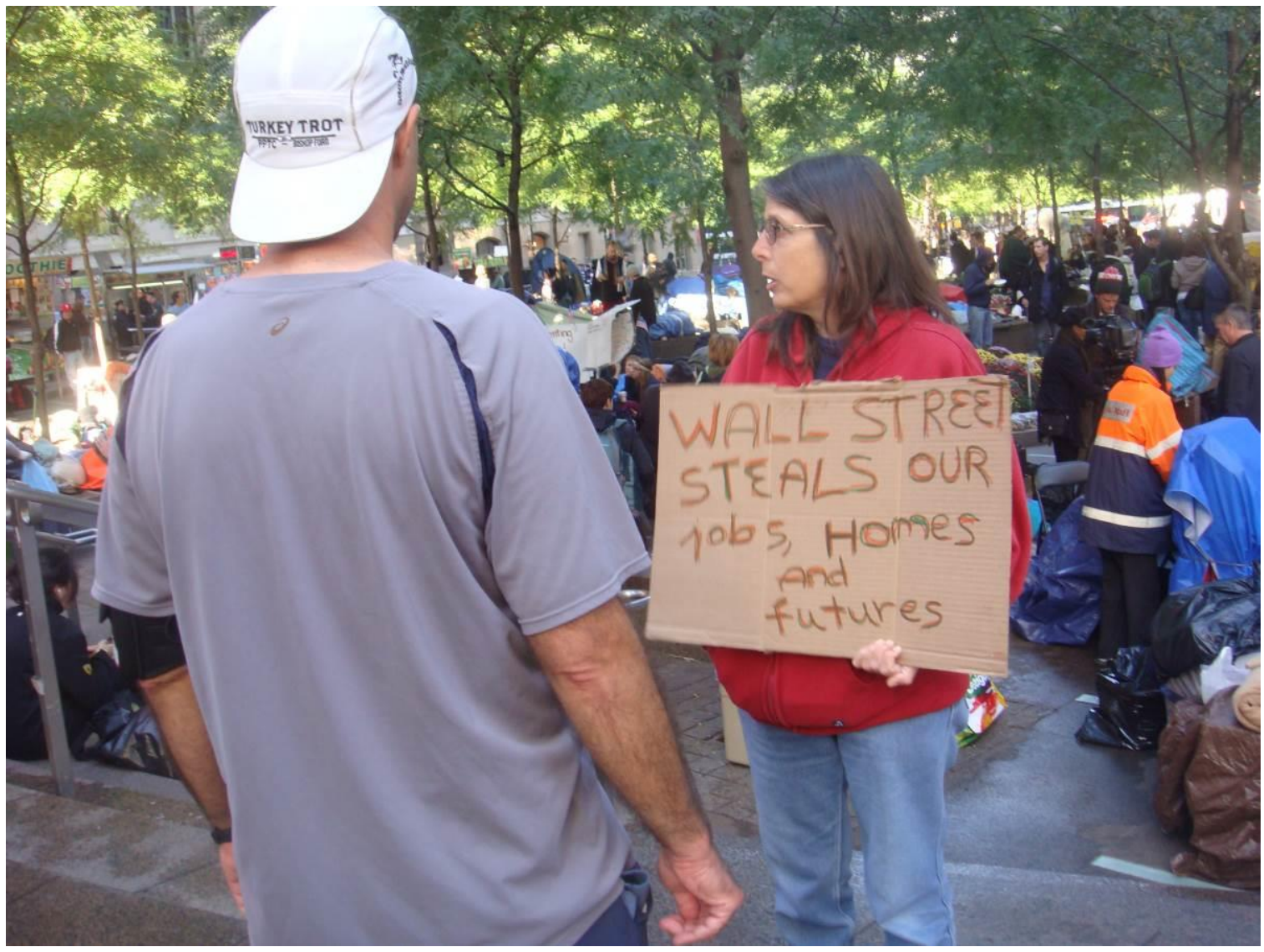

\section{Part 1: Occupy's Challenge from Below}

Before suddenly becoming a consequential movement, Occupy Wall Street started as just another odd instance of marginal opposition by fringy New York City activists. But, in less than sixty days, the 2011 movement drastically changed the terms of national political debate and propelled radical critiques of finance into mass circulation. Occupy erupted from the margins into the mainstream where loosely-allied movements delivered a heterodox message into the teeth of power, provoked a response, and accumulated large financial and material assets which required banking and warehouse services. As it gained material, financial, and political clout, Occupy assembled multiple unauthorized discourses against Wall Street financial firms recently impervious to criticism or opposition. As occupations spread to many towns and cities, and a protest camp in Zuccotti morphed daily into an all-purpose opposition center on illegally-seized land, Occupy developed into a consequential threat to elite rule. 
How, then, did Occupy develop into a threat? What were the conditions that allowed Occupy's oppositional themes and utterances to gain wide circulation and high profiles? How did Occupy amplify the discontented voices of ordinary people?

Figure 2: At Zuccotti Park, tourists stopped to check out the many intriguing spectacles.

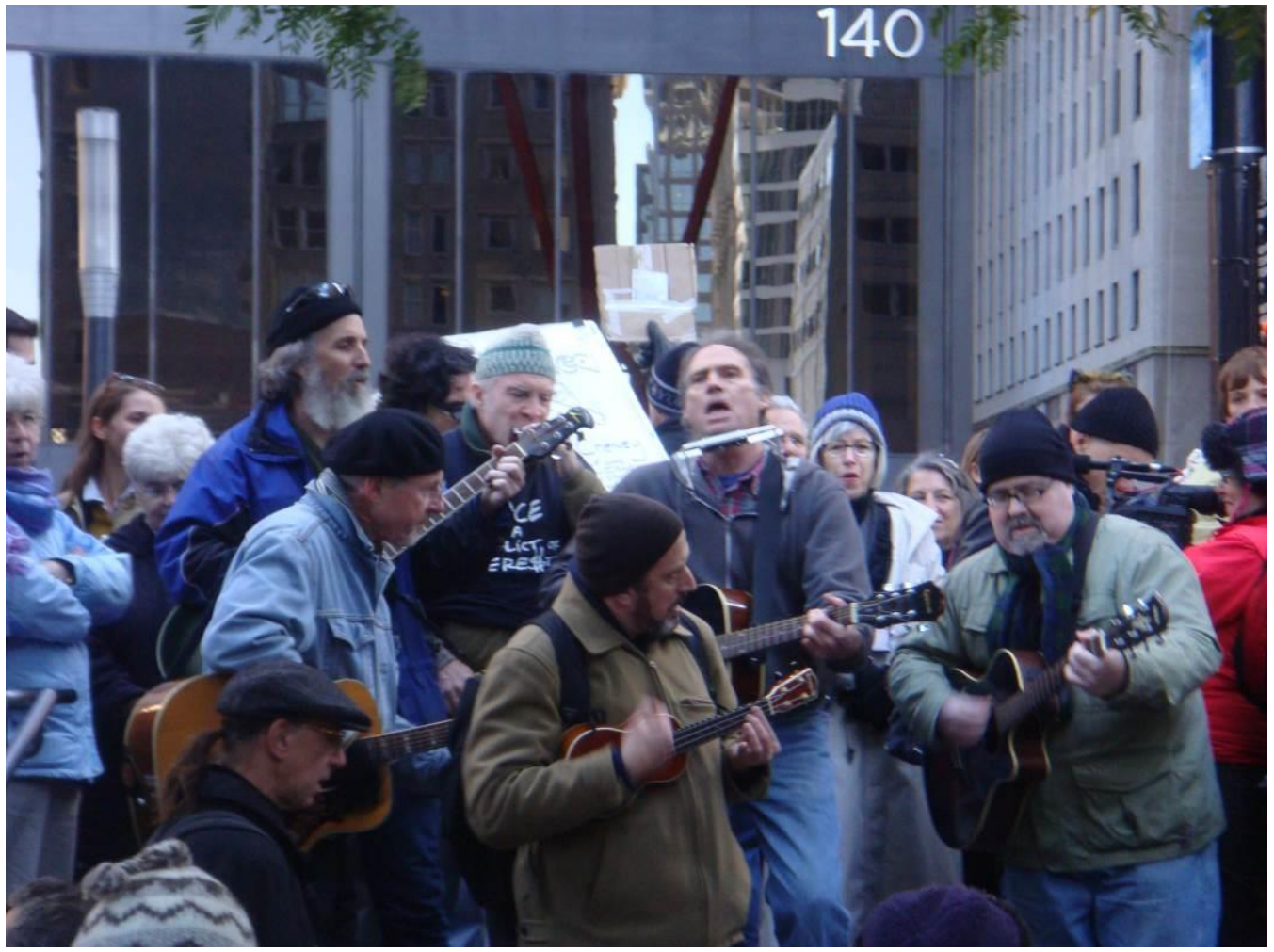

\section{Physical Occupation of Meaningful Space}

The first communications' strategy that I discuss, because I believe it is most important, is the physical placement of a protest encampment on the streets of Lower Manhattan without permission. Occupy gained mass circulation because it imposed on public space, public attention, and mass media a spectacle with a long enough life to attract attention and thus compete for the attention of American viewers. Camping out illegally on Wall Street amplified outraged voices of ordinary people by being long-term, not transient like a march or a rally.

On the $17^{\text {th }}$ of September, several hundred activists associated with Occupy set out to occupy Chase Manhattan Plaza, one short block from the New York Stock Exchange, but the police had surrounded the plaza with barricades. Unsurprised, Occupy's Tactical Working Group (TWG) consulted their list of seven alternative spaces. These alternative spaces were a closely guarded secret in the lead-up to the $17^{\text {th }}$, but when Chase was ruled out, TWG spread the word that Zuccotti Park, a "privately-owned public park" three blocks from the Stock Exchange, was next on their list.

Demonstrators found Zuccotti free of barricades and moved in. To their surprise, police did not move against them, and they woke up the next day residents of the Park. Mitchell L. Moss, Professor of Urban Policy and Planning at New York University, explained the City's inaction: "The City had a policy for encouraging commercial developers to create open space in exchange for more height. But until now, no one has thought about the issue of what the rules are" (Foderaro 2011). The core activists of Occupy, by poking at the downtown 
landscape, looking for fissures in the state-corporate entente, had found one they could pry open - a privately-owned public park with hazy rules and complex ownership.

Zuccotti Park's private-public arrangement was a vulnerability waiting to be exploited, but in 1996, when Brookfield Properties, Inc., took possession of the space, they could not have expected that a protest encampment would expose the legal contradictions. They were not prepared. John Zuccotti, the former Brookfield executive for whom the park is named, said, "We basically look to the police leadership and mayor to decide what to do" when complications arise at the park, while Mayor Bloomberg explained that the Occupiers weren't evicted because Brookfield hadn't requested it. In other words, when the Occupiers arrived on September $17^{\text {th }}$, both Brookfield Properties and New York City officials incorrectly assumed that the other would respond. Neither did. (Roberts 2011)

Occupy sought a spot in the immediate vicinity of Wall Street because they identified banks as the place where people could assemble and petition the elites who rule daily life. In the lead up to the occupation, the Anonymous hacking group issued several communiqués arguing that Wall Street was the place to gather because "the banksters" had cratered the national economy and then rewarded themselves with bonuses paid for with taxpayer bailouts. Anonymous addressed the criminals of Wall Street directly:

Perhaps you think you are at the eye of storm, luxuriating in tranquility while all around is ripped apart and made anew. But it is not so... You are at the center of the crosshairs!... You have crystallized this country into a monolithic tyranny and in doing so you made brittle the ties that bind people. We are here, gathered at the steps of your butcher block four years later, frenzied and furious. Your crimes have united this great melting pot into a white-hot alloy of rage. ("Anonymous Press Release for Occupy Wall Street Action," 2011)

In the parlance of urban youth, Anonymous and other Occupy participants "recognized"; they publicly acknowledged what is going on and who the central perpetrators are.

In a talk that I attended at Hunter University in late 2011, Cornell West expressed support for the choice of Wall Street as the right target for protests because dominant control of society is in the private hands of finance. To support his claim of Wall Street dominance, West pointed out that, before the deregulation of finance, business, and industry by government began 30 years ago, the financial sector took in no more than 16 percent of overall profits but in the last decade this sector has taken up to 41 percent. He connected the financialization of our economy to American society's "gangsterization" - putting profits before people.

In their open-air public space on the footsteps of Wall Street, Occupy participants asserted oppositional sentiments, radical social values, anti-market ideas, and even revenge fantasies which dared Wall Street financiers and the Mayor's Office to stop them. Thousands of outof-town tourists walking past the park could view "Wanted!" signs portraying criminal bank executives like Angelo Mozillo, a six-foot wolf puppet holding a sign that read "The Wolves of Wall Street Give Wolves a Bad Name," and then take home with them newsletters devoted to reporting on "what the $1 \%$ don't want us to think about." Such egalitarian materials could not reach such a large audience before the occupation of Zuccotti created a mass disruption in the status quo. Writing from a public relations standpoint, in an October 6th New York Times op-ed, Richard Beales (2011) lauded Occupy for "picking a good spot," saying that the crowds and street theater made for good television, and also that, because camping in front of Wall Street could be very costly to the demonstrators, their daring had won them notoriety. 
Figure 3: Sign in Zuccotti Park.

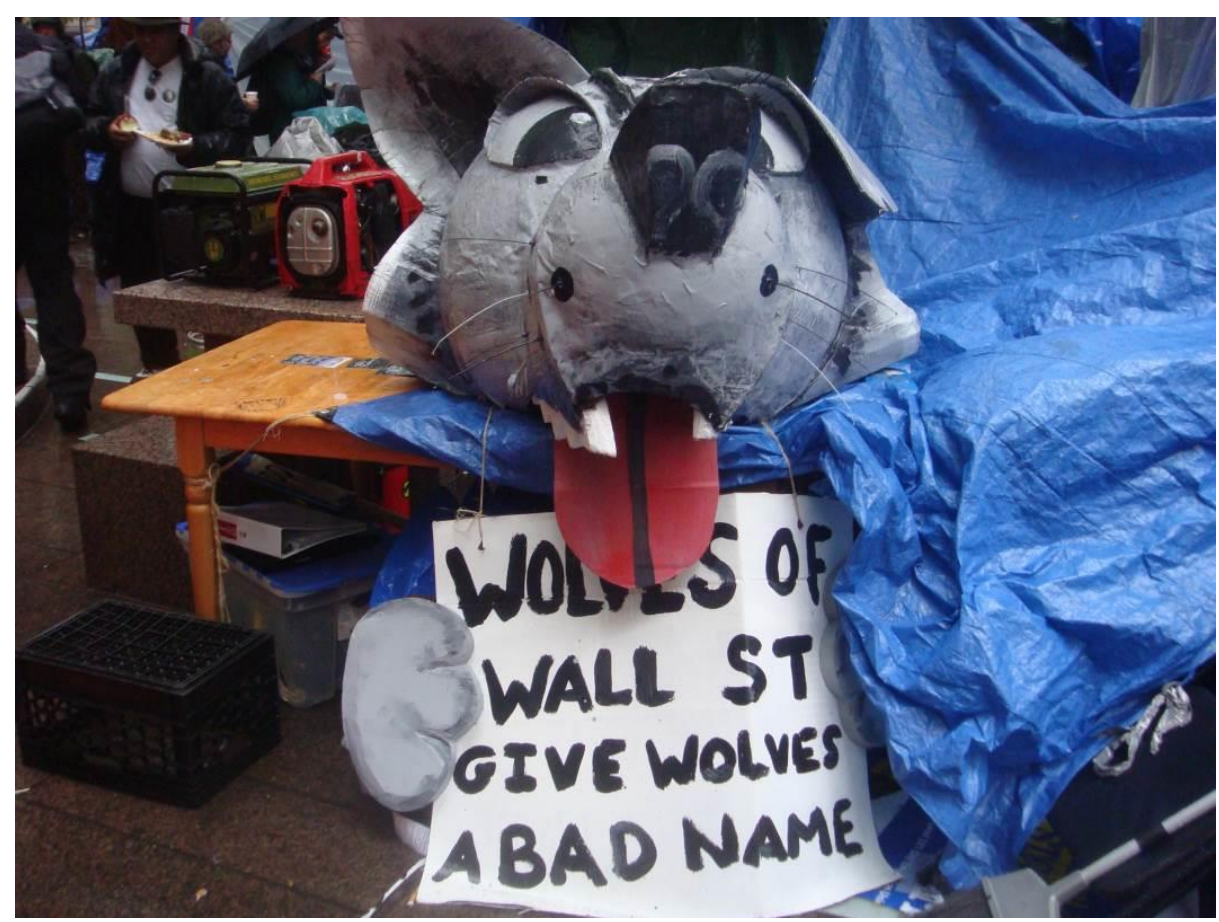

Figure 4: Protester holding sign in Zuccotti Park.

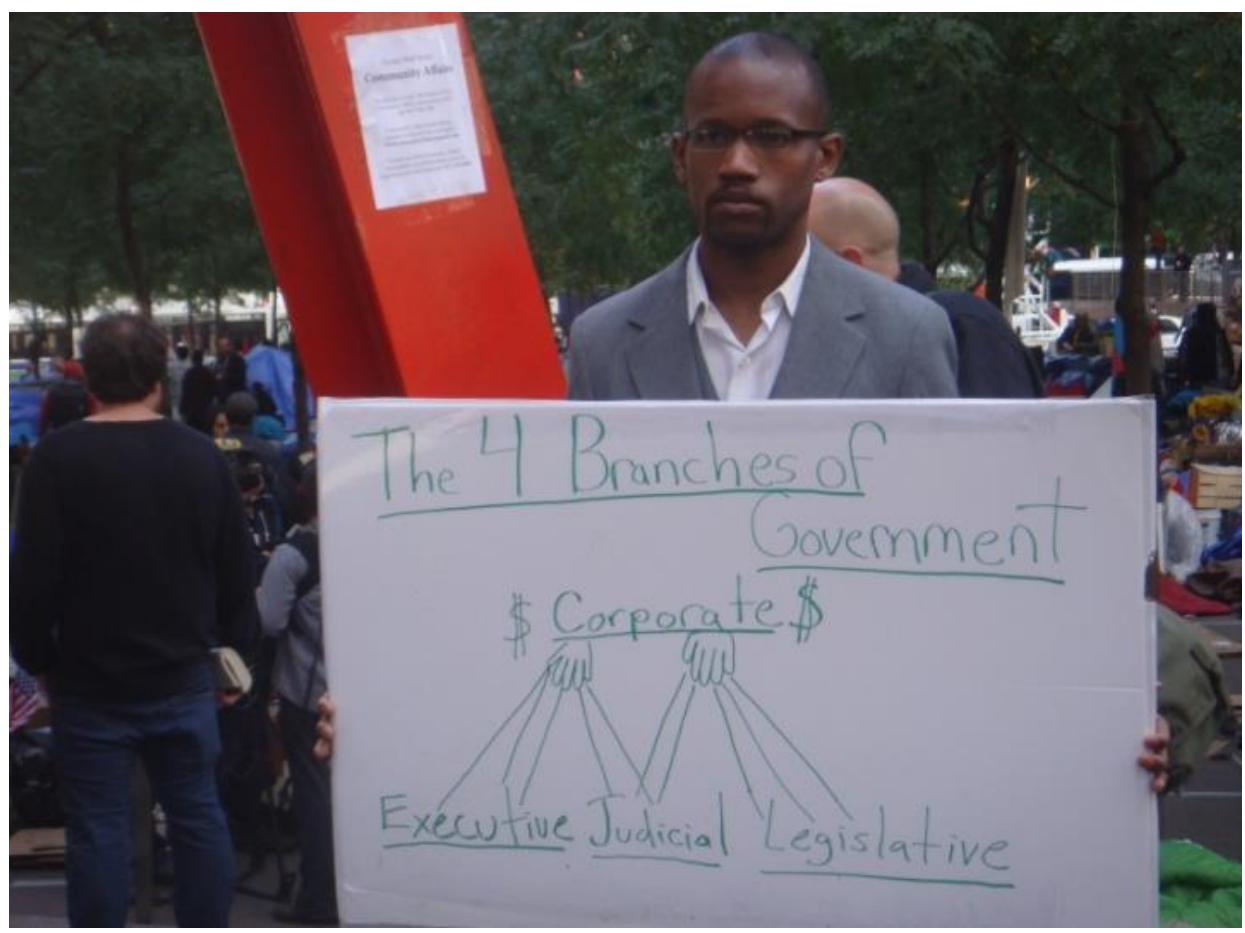


Figure 5:Tourists in Lower Manhattan frequently stopped to take pictures of the Zuccotti encampment.

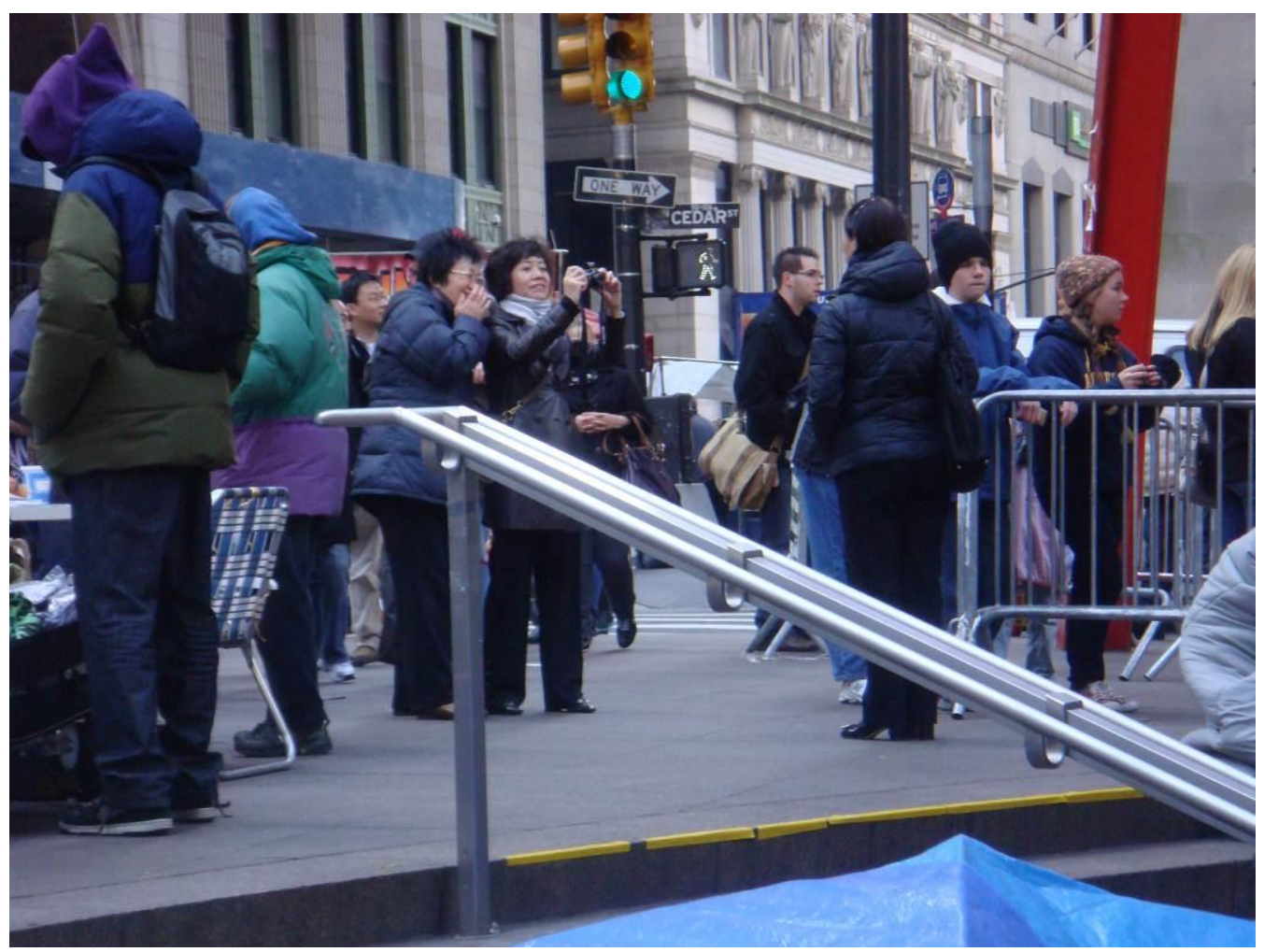

Occupy posed a threat to the status quo because it performed alternative social relations as it critiqued existing ones. As weeks of occupation went by, the camp evolved to house hundreds of overnight campers, thousands of daily visitors, and an array of free services like meals, health care, clothing, phone calls, education, books, shelter, even cigarettes.

In addition to viewing the displayed alternatives, people walking past the park could clear up any doubts they had about Occupy and get answers about what confused them about the movement. One morning in early November, for instance, I witnessed an elderly couple stopped on the sidewalk to peer in at the interior of the park. Since they were within shouting distance of the west side Welcome Station, the guy working that station shouted out to them jovially, "Go ahead in! We're not crazy like the news says we are!" The woman in the couple said, "Well, I know that!" at which point the couple ambled into the park to get a closer look at things.

I also witnessed adults using the encampment as a learning opportunity for kids. The sight of children being escorted through the park by approving schoolteachers grew common by November. Occupy demonstrators worked to accommodate kids by adding a children's section in the Occupy Library, by discouraging each other from cursing when kids were around, by providing fascinating puppetry and pageantry on Halloween, and by improving walking lanes in the park. The attraction of kids to the park was yet another reason for authorities to feel threatened - Helaine Olen (2011) of The New York Times expressed amusement over a four-year old kid holding a sign promoting economic justice at Zuccotti Park, noting that four is "an age when girls are generally thought to be more interested in Disney characters than protest marches." 
Figure 6: Students studying Occupy Wall Street at Zuccotti Park

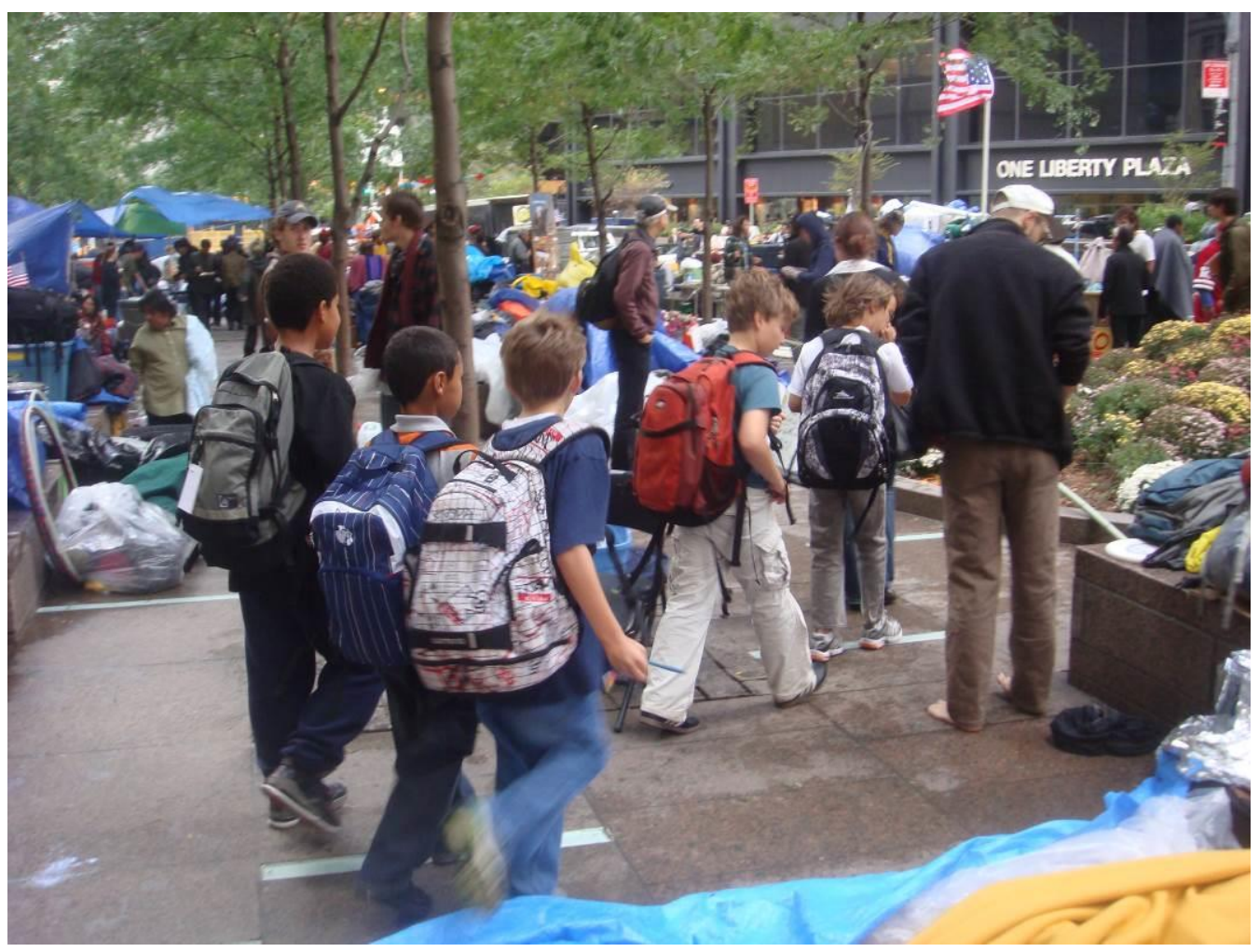

Figure 7: Students studying Occupy Wall Street.

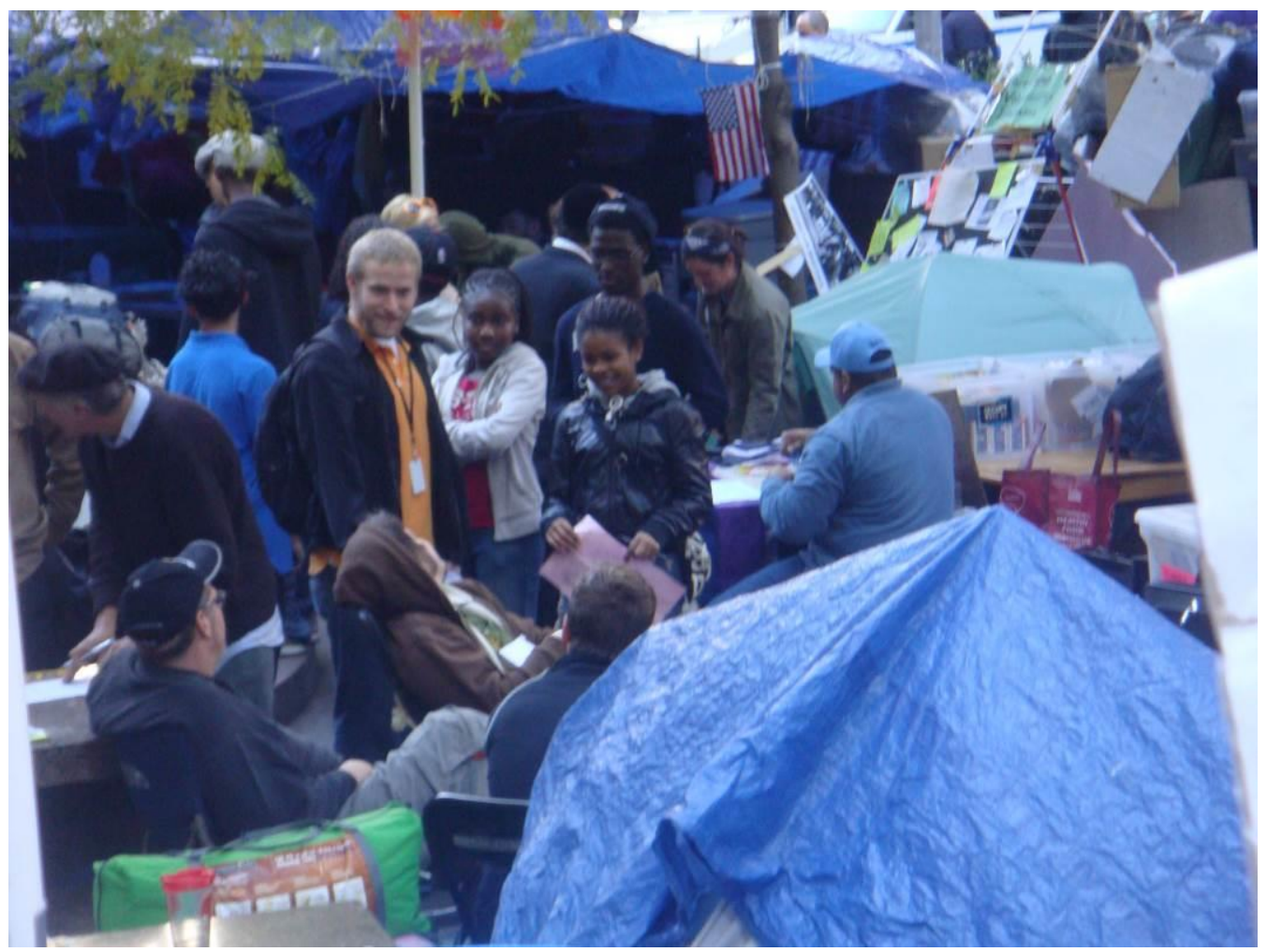


Figure 8: Students studying Occupy Wall Street.

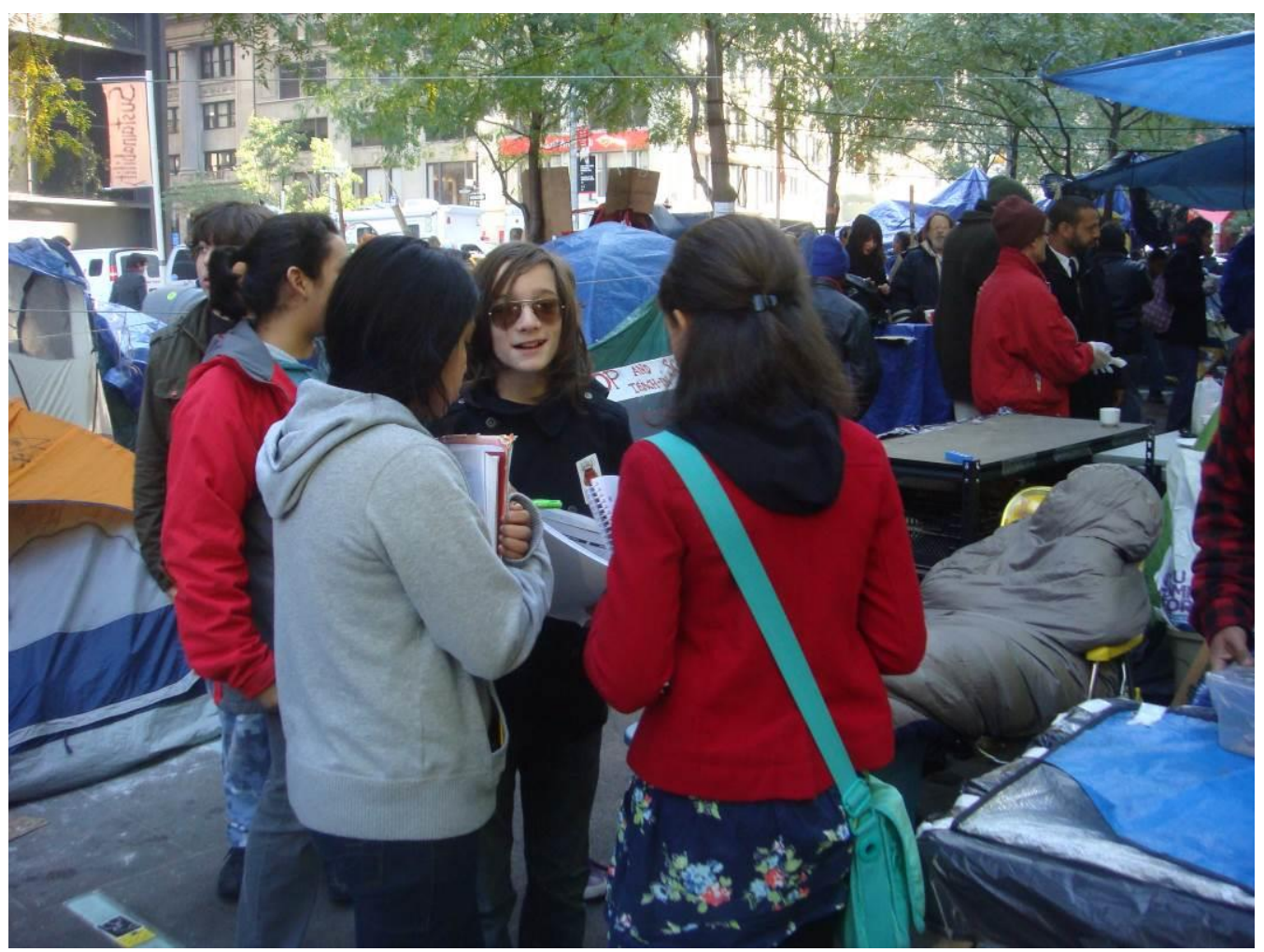

Tourists wandering Lower Manhattan - or riding by in double-decker tourist buses - snapped countless photos of Zuccotti Park, its inhabitants, and signs on display. These tourists with their cameras augmented Occupy's ability to bypass the mainstream media to gain wider circulation.

Just in case they weren't planning to already, demonstrators asked tourists to upload their photos to Facebook. An Occupier from China, for example, had a sign hanging around his neck reading "Protect Humanity's Peace, Freedom, Democracy... A Long Way To Go." After tourists took his picture, he showed them a note on the back of his sign reading "please post to Facebook." Ideally, tourists from America's heartland or from overseas would circulate their photos of Occupy within their own social networks. The picture of a smiling, friendly Chinese man promoting a message with universal appeal might counter some of the negative images people had seen from the major media. 
Figure 9: This demonstrator could be found at the edge of Zuccotti Park nearly every day that I visited.

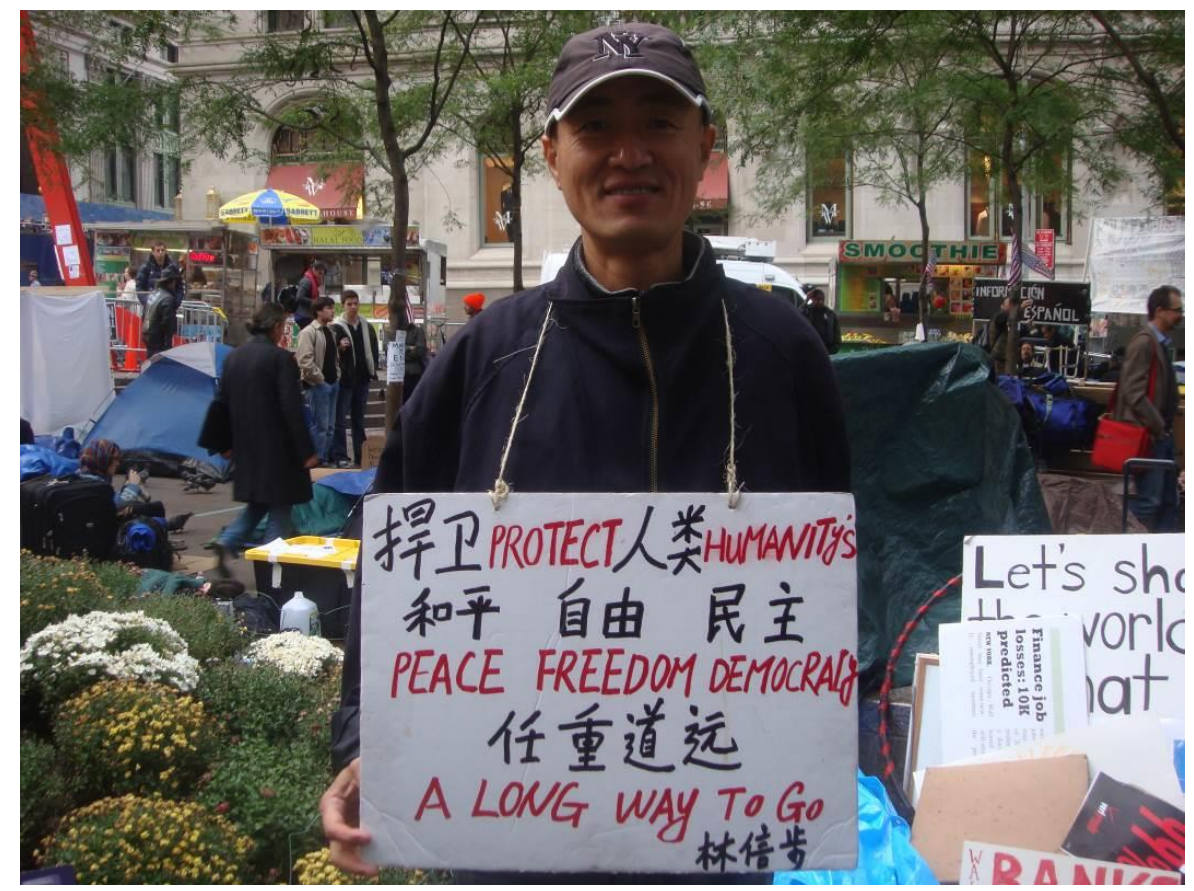

\section{Unsupervised Channels for Circulation of Unauthorized Discourse}

As I describe in Part Two of this article, Occupy's relationship with major media was much more complex than their relationship with tourists passing by the park. Mainstream channels did not usually treat Occupy's message favorably, so Occupy wisely developed its own channels for circulating discourse. One of Occupy's most famous tools for circulation was the Occupied Wall Street Journal (OWSJ), a hand-distributed print organ that riffed off The Wall Street Journal but disseminated news and opinion from the point of view of the protesters. The idea for the $O W S J$ came about because, according to editor Arun Gupta, "we didn't think there would be much in the way of coverage of the event, so we thought it was important that there be a media outlet that reflected what was under way" (Carr 2011). Besides hawkers distributing this alternate broadside at Zuccotti Park and at off-site rallies, its circulation occasionally copied that of the major dailies in New York City. For example, at the height of the movement, I was able to find stacks of OWSJ sitting alongside stacks of the New York Post and New York Times at a convenience store in the neighborhood where I live, 5 miles from Zuccotti Park.

Occupy developed online channels as well as print ones. Within Zuccotti Park, activists constructed a "Freedom Tower," composed of two modems and six radio antennas. The tower distributed wireless Internet access open to everyone who visited the park. The excellent wireless access in the park aided Occupy's Twitter campaign as they blasted out pro-Occupy and anti-Wall Street messages every minute of every day. 
Figure 10: Freely accessible WiFi made Zuccotti Park a good place to broadcast Occupy discourse.

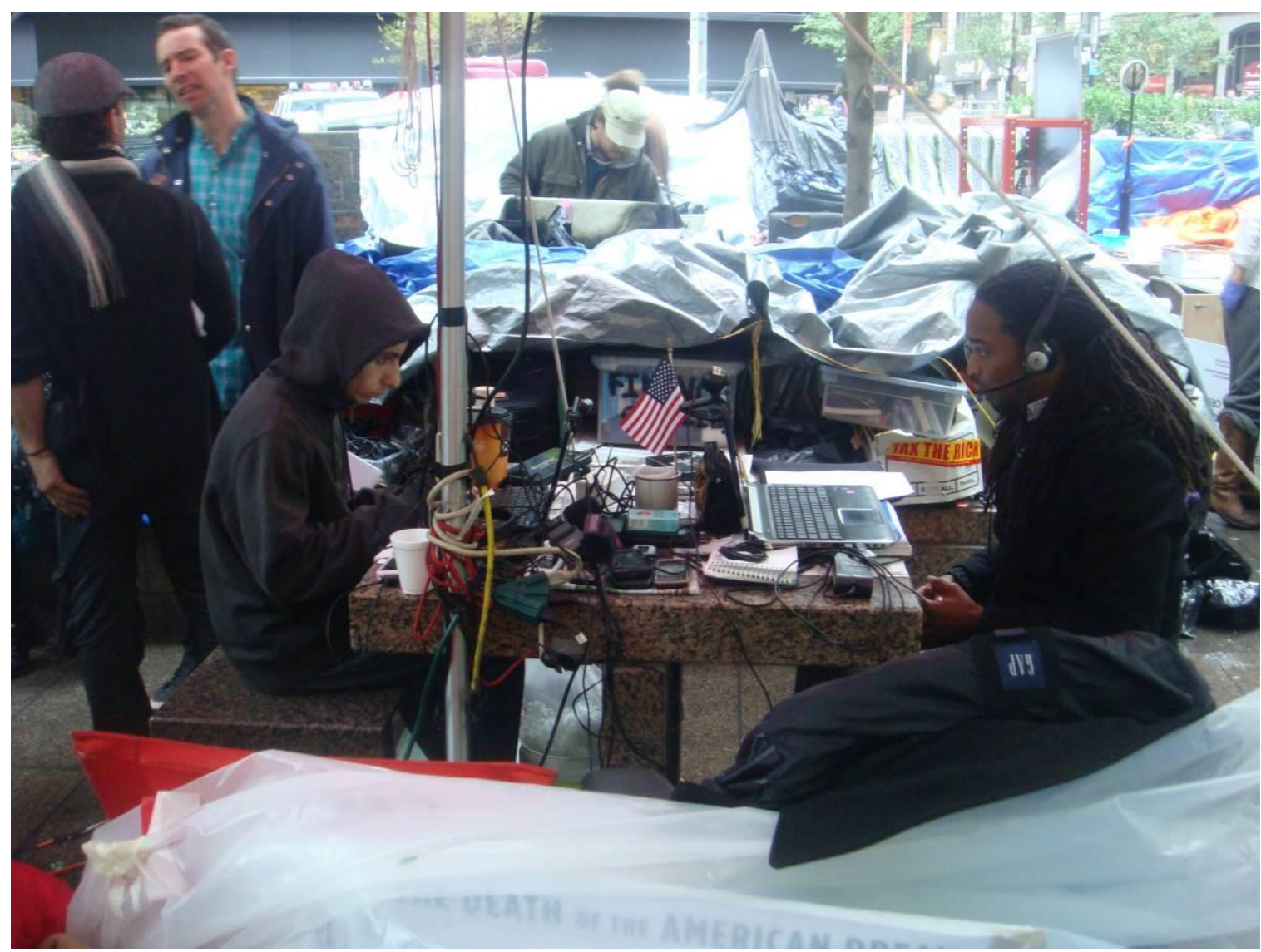

Awareness of Occupy escalated after the Occupy Media Working Group circulated videos of a disturbing incident during a September 24th march to Union Square. The videos showed several marchers who had been kettled into a netted sidewalk area and who were not trying to force their way out. Among them was an apparently non-violent young woman named Kaylee Dedrick. The videos, "made by several protesters at different vantagepoints" (Baker and Goldstein, 2011), show Dedrick being pepper-sprayed by NYPD Deputy Inspector Anthony Bologna, causing her to collapse in shrieks as Occupy medics rush to help her. The sensational and troubling video went viral and aroused new sympathy for Occupy and hostility toward the NYPD from people outside the movement. According to a New York Times report on September 29th, the videos

have prompted a level of criticism of the police rarely seen outside of fatal police shootings of unarmed people. The independent city agency that investigates accusations of police abuse said that about 400 people had complained, many from out of state. (Baker and Goldstein 2011)

Through its own channels, Occupy was able to circulate the pepper-spray video and force into national attention what was going on in Lower Manhattan. The major media were not able to quarantine the wave of sympathy that this filmed incident provoked. People who been privately seething about the bailout of Wall Street after its greed had torpedoed the global economy in 2008 now became fans rooting for Occupy and following its adventures. 


\section{A Radical Critique of Finance Acheives Widespread, Sustained Circulation}

In its earliest incarnation, Occupy was just one of many oppositional groups operating in the margins; during September 2011, Occupy news never occupied more than 2 percent of the nation's collective coverage, according to Pew's Research Center for Excellence in Journalism. In fact, Occupy did not even register on the Pew charts until the very end of September. (Holcomb, 2011)

However, in the first full week of October, coverage of Occupy jumped to 7 percent of the nation's collective news coverage (Holcomb 2011). An avalanche of unsupervised, horizontal communication online and onsite provoked the mainstream media to begin covering the movement more energetically. Occupy's share of the national news jumped to 10 percent in the second week of October before leveling out at around 5 percent. The news media had signaled, merely by the amount of coverage it was supplying, that Occupy was important, that it mattered, and that it had traction.

By early October, Occupy was internationally known and strong public support for the movement meant that the New York City officials could not peremptorily remove the activists without seriously harming the credibility of the police and the Mayor. A Quinnipiac poll of New York City voters released in mid-October found that nearly three-quarters said that they understood the protesters' views at least fairly well and two-thirds said that they agreed with those views. Nationwide, the support was just a bit less, hovering around sixty percent. (Muskal 2011)

\section{Part 2: Beating Back Occupy's Challenge}

This section examines the dominant elite's efforts to reassert control of mass representation and public discourse in the face of a non-violent movement's challenge to the dominant media's pro-business narratives. Plan A - ignoring the demonstrations - proved ineffective because Occupy had leveraged its own communication systems to circulate its anti-corporate message to a wider and wider audience. Plan B - tarring Occupy as unworthy of association had limited success because Occupy's message had mass legitimacy after the trillion-dollar bank bailouts in 2008. After these "soft means" for remarginalizing Occupy were found ineffective, authorities - with Mayor Mike Bloomberg leading the way - turned to police violence.

\section{Plan A: Ignoring or Downplaying Occupy}

Although Occupy's Lower Manhattan actions began in early September and the occupation of Zuccotti Park began on September $17^{\text {th }}$, news about Occupy never occupied more than 2 percent of the nation's collective coverage during the month of September (Holcomb, 2011). For most of September, Occupy coverage was too scant to even register in the Pew rankings (Holcomb 2011). In Domination and the Arts of Resistance, James Scott offers the following explanation for why dominant groups might downplay or ignore opposition: "When it suits them, the dominant may elect to ignore a symbolic challenge, pretend they did not hear it or see it, or perhaps define the challenger as deranged, thus depriving his act of the significance it would otherwise have" (1990: 205).

Those members of the mainstream media who did not ignore Occupy during its first few weeks often depicted the movement as incomprehensible or insignificant. In Gina 
Bellafante's analysis piece on Occupy, "Every Action Produces an Overreaction," published in The New York Times on October $2^{\text {nd }}$, she argues that nothing remarkable was going on at Zuccotti. "The most threatening thing happening at this disorganized affair," she wrote, was that people were "reading Orwell."

After the online circulation of videos showing Deputy Inspector Bologna pepper-spraying Kaylee Dedrick, editors at The New York Daily News (NYDN) came to the aid of Police Commissioner Ray Kelly and Mayor Bloomberg in an October $7^{\text {th }}$ editorial, suggesting that no one, in fact, had engaged in cruelty toward the demonstrators. NYDN editors used their platform to downplay violence committed by the police and dismiss the outrage expressed by Occupy participants and their supporters. The editorial, titled "Occupy Wall Street protesters need to start living in the real world," referred to "squirts" of pepper-spray and "less-thanbruising whacks of a nightstick on a backpack." The Daily News editors encouraged "the whiners" to do a Google search for "videos of Chicago Police outside the 1968 Democratic Convention." Viewing those videos would purportedly give demonstrators (and their supporters) a sense of how comparatively mild the police violence toward Occupy has been. One month later, in yet another editorial show of support for the NYPD, Daily News editors dismissed Occupy demonstrators as "tots throwing tantrums," thereby reinforcing what Bellafante and others had been circulating throughout October - that Occupy participants are merely "protesting for protest's sake."

Although leading factors in the media represented Occupy as insignificant and/or lacking a comprehensible message, one might say that Occupy was obvious in its critique of the great inequality of wealth and power in the United States. Activists had gathered to protest things that are quite meaningful to regular Americans: corporate influence in American politics, a federal response to the 2008 financial crisis that was heavily biased toward the rich, war profiteering, declining access to education, etc. Despite the widely-circulated "protesting for protest's sake" meme, there is evidence that members of the public were not having a difficult time deciphering Occupy's message. According to one poll released by Quinnipiac University on October 17th, $72 \%$ of New Yorkers understood the demonstrators' views "fairly well" or "very well" (Oresmus 2011).

Allowing Occupy to continue might have further mainstreamed their widely-shared feelings about economic inequality that elites preferred to keep repressed. Although the movement had been launched by a relatively small group of anarchists and other dissidents, it attracted and consolidated many forms of unauthorized discourses against the status quo.

\section{Plan B: Undermining Opposition Once They've Reached Mass Circulation}

By mid-October, with Occupy's discourse circulating heavily through mass media outlets, defining the movement merely as "unclear" or "insignificant" would not suffice. Remarginalizing this robust opposition to Wall Street dominance required that Occupy be redefined in the public mind as dangerous fringe elements, or, in the words of New York Post columnist Steve Cuozo (2011), "anarchists, vagrants, and zanies" driven "by a nihilist impulse to disrupt life and commerce." Although planning for such a rhetorical offensive might be expected to occur behind the scenes, Congressman Peter King, who represents the $2^{\text {nd }}$ District of New York, went public on October $7^{\text {th }}$ with a plea for the media to undermine Occupy's credibility. "It's really important for us not to give any legitimacy to these people in the streets," King said on Laura Ingraham's right-wing radio show, adding, "I remember what happened in the 1960s when the left-wing took to the streets and somehow the media glorified them and it ended up shaping policy. We can't allow that to happen" (Miller 2011). 
Figure 11: At Zuccotti Park, demonstrators displayed The New York Post's latest smears against them.

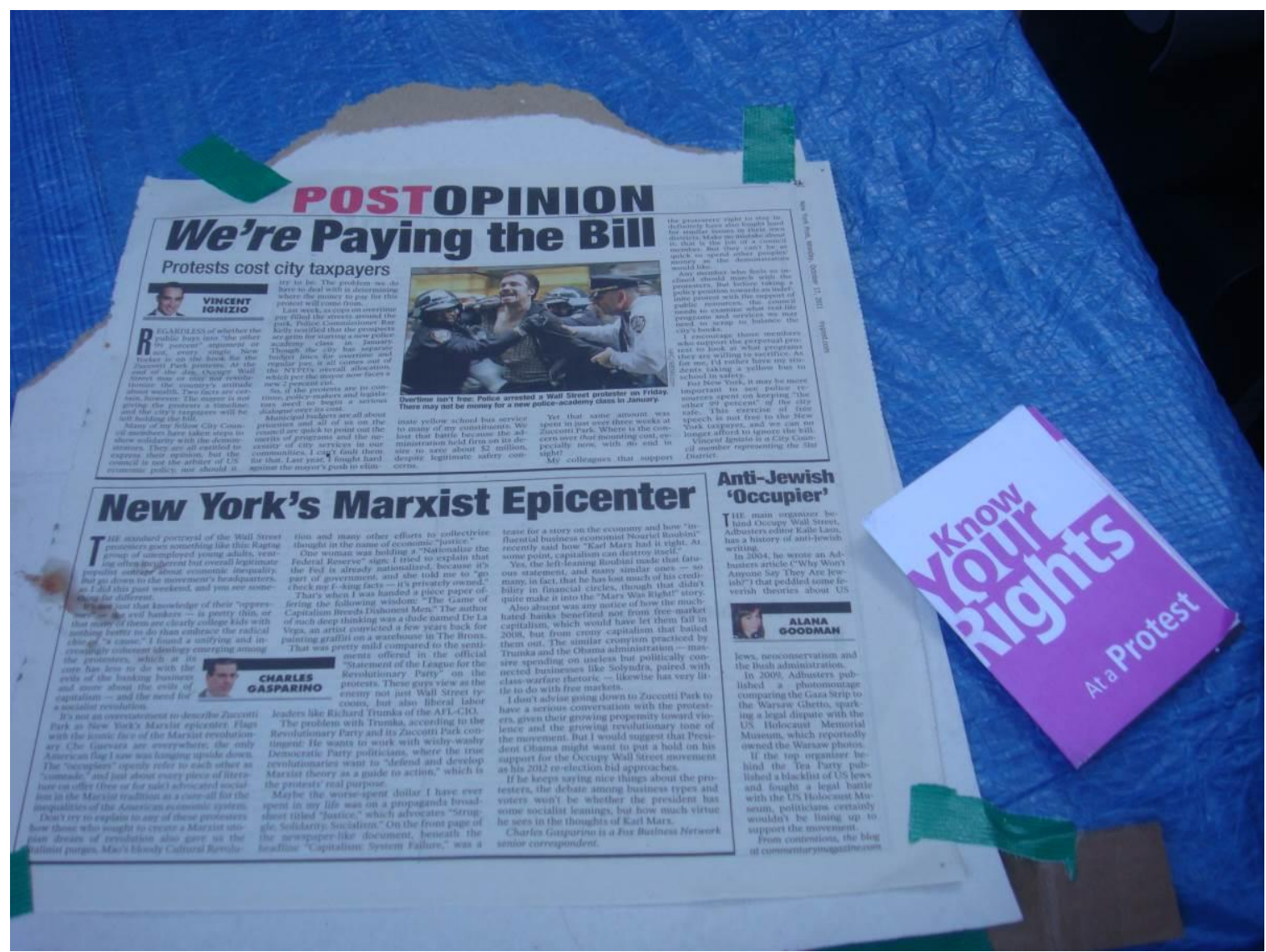

Rep. King's proposal to undermine the legitimacy of Occupy resembles schemes that authorities often deploy, according to James Scott (1990), in order to keep opposition groups from gaining "the status in public discourse they seek" (206). In civilizations around the globe, Scott has found that, through control of mass communications, elites can "assimilate the opposition's acts to a category that minimizes its political challenge to the state" (206). Scott points out, for example, that "there is little doubt that it often serves elites to label revolutionaries as bandits, dissidents as mentally deranged, opponents as traitors" (206).

The New York Post circulated dozens of articles portraying Occupy as, at best, a drag on ordinary people's quality of life. For instance, on October $16^{\text {th }}$, City Councilman Vincent Ignizio (2011) published an op-ed in The Post arguing that "we cannot keep footing the bill for these protests," which he said cost the city millions of dollars in overtime for police officers and which might force cancellation of a new police-academy class scheduled for January.

Ignizio's commentary represented just a single shot at Occupy in a volley of discharges from The Post. On the day after Occupy was evicted from Zuccotti on November $15^{\text {th }}$, reporters for The Post admitted, "The Post has led the charge to shut down the Occupation - after exposing how a large number of the park's OWS inhabitants were freeloaders and ex-cons who were not supporting the cause. The paper called on city leaders to return the space to its intended purpose" (Gregoran, Sutherland, and Fredericks 2011). Articles within The Post suggested, among other things, that demonstrators advocated bloody revolution (Saul 2011), that they were led by an anti-Semite (Goodman 2011), and that the park "smelled like an open sewer" (Cartwright and Fredericks 2011). 
For Todd Gitlin (2011), a professor of journalism and sociology at Columbia, the expressions of disgust by commentators in The New York Post were to be expected. Gitlin wrote in a New York Times op-ed,

If some aspects of the Occupy Wall Street protest feel predictable - the drum circles, the signs, including "Tax Wall Street Transactions" and "End the FED" — so does the right-wing response. Is it any surprise that Fox News and its allied bloggers consider the protesters "deluded" and "dirty smelly hippies"?

Perhaps more surprising were the smears against Occupy that emerged from seemingly nonpartisan news outlets. For example, a free newspaper called Metro New York ran a front page article on October $23^{\text {rd }}$ which claimed incorrectly that core Occupy activists were hoarding hundreds of thousands of donations and using the money for luxuries like "gourmet dinners, down blankets, and flat-screen televisions" (Epstein 2011).

\section{Plan C: Turning to Monopoly on Violence}

As I have shown, the mainstream media first tried to downplay the significance of Occupy by ignoring it or representing it as "protest for protest's sake." But that couldn't keep Occupy's message from gaining mass circulation, so members of the mass media tried a second technique - undermining Occupy's legitimacy by depicting the group as unworthy of association. However, these tactics yielded limited success in remarginalizing Occupy because Occupy didn't invent the anger at Wall Street. It only forced it onstage, acting against and for things which spoke to orientations that are widely felt but rarely acted on in public. Alexander Stille, Professor of International Journalism at Columbia, wrote, in a New York Times op-ed published on October $19^{\text {th }}, 2011$,

In an era in which money translates into political power, there is a growing feeling, on both left and right, that special interests have their way in Washington. There is growing anger, from the Tea Party to Occupy Wall Street, that the current system is stacked against ordinary citizens.

Polls support Stille's contentions. In February 2011, for example, seven months before the occupation of Zuccotti Park, a Gallup poll found that $67 \%$ of Americans were dissatisfied with "the size and influence of major corporations in America today" (Saad). A New York Times/CBS poll taken in October 2011 found two-thirds of Americans want wealth to be distributed more equally while the same amount object to tax cuts for corporations (Zeleny and Thee-Brenan 2011).

Occupy's ferocious circulation of anti-Wall Street discourse from its unauthorized staging area uniquely consolidated, propelled, and projected popular opposition to a financial and political system that was at its most vulnerable moment, a financial collapse revealing how the status quo socializes risk and privatizes profits, that leaves some bankers wealthy and many citizens indebted. Therefore, "soft," discursive, means for remarginalizing OWS could not, on their own, push OWS discourse back to the margins. 
Figure 12: The Zuccotti encampment was cleared by the NYPD on November 15th.

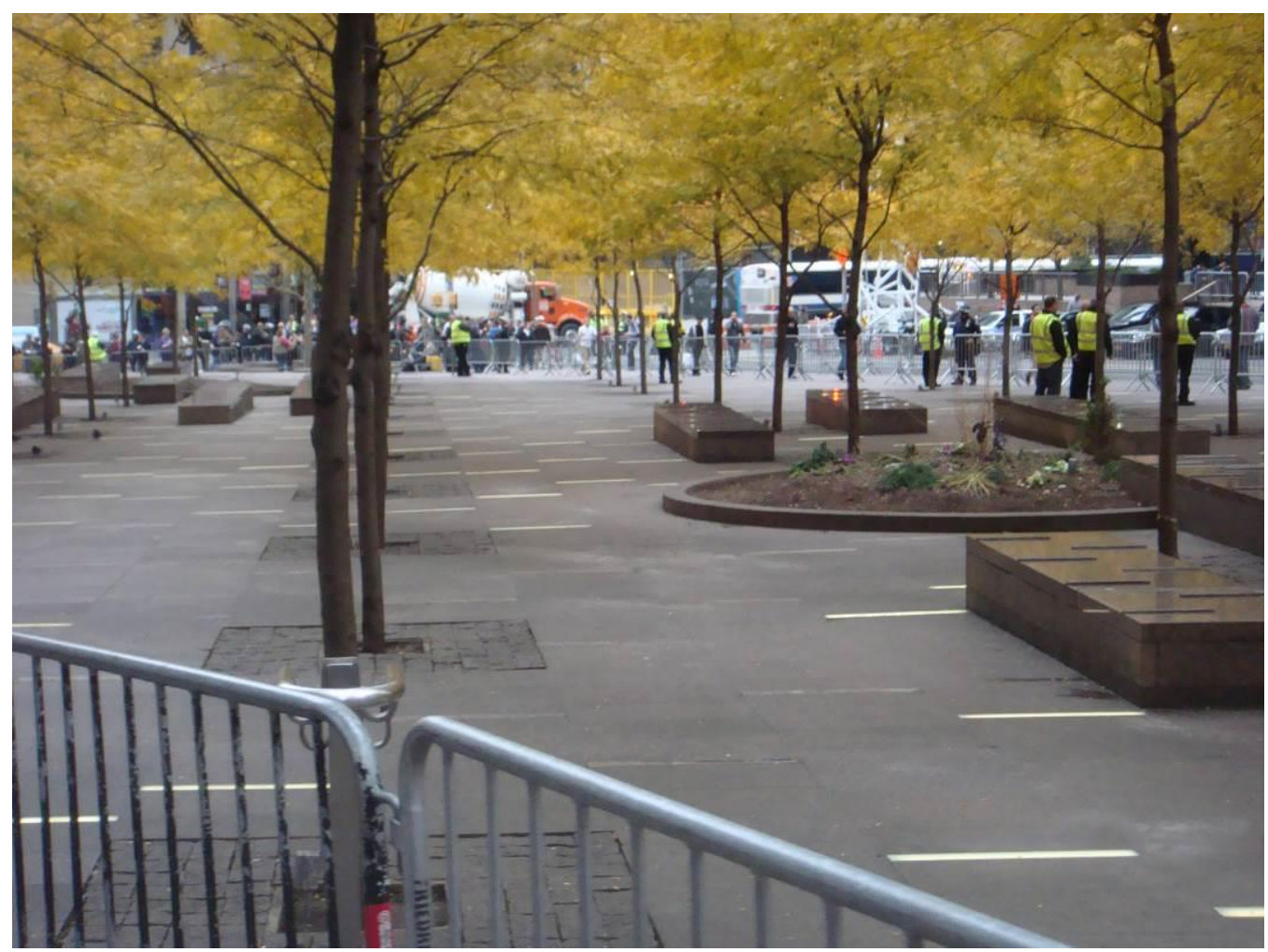

The City's first eviction attempt occured on October 14th. Mayor Bloomberg had moved to clear the camp but the Mayor and the police had telegraphed their plans, allowing the opposition to prepare for what seemed like a daylight raid with journalists attending. The attempt failed, thwarted by 1) mass support for the camp expressed in many calls and emails to the Mayor from liberal politicians and others, 2) the onsite civil disobedience of Jesse Jackson who linked arms in the park with occupiers when a police attack was rumored, and 3) the many hundreds who came downtown to physically defend the encampment (Barbaro and Taylor 2011). In a New York Times report, Michael Barbaro and Kate Taylor wrote, "By 6 a.m., just before City Hall announced the cleanup was canceled, the crowd had grown to more than a thousand, their numbers swelled by Internet pleas for reinforcements." The idea of a violent battle between the police and 1000 Occupy participants didn't seem like a good idea to many powerful politicians in New York. Barbaro and Taylor elaborated,

Behind the scenes, interviews suggested, the change in course was fueled by an intensifying sense of alarm within city government, shared even among some of those who work for Mayor Michael R. Bloomberg, that sending scores of police officers into the park would set off an ugly, public showdown that might damage the reputation of the city as well as its mayor.

Clearing Zuccotti Park required that the city win the image wars, and the October 14th attempt was not equipped to do so.

However, by the November $15^{\text {th }}$ eviction, Mayor Bloomberg had learned his lesson well. The NYPD won the final battle of the images because City authorities destroyed the encampment with police power in the middle of the night, with all news media quarantined and no live coverage possible. Reporters in the park with press passes were forced to leave and placed in 
a "free-press zone" (Gillham, Edwards, and Noakes 2013) where they were unable to witness or collect video on the confrontation.

According to police spokesman Paul Browne, the creation of the free-press zone was for the journalist's own safety, comparing the perimeter for the press to perimeters created around crime scenes and calamitous events. Mayor Bloomberg said that the media was kept away "to prevent a situation from getting worse and to protect members of the press." But several journalists and journalism groups spoke out against the police tactics.

- The New York Press Club said in a statement that "the brash manner in which officers ordered reporters off the streets and then made them back off until the actions of the police were almost invisible is outrageous." (Stelter and Baker 2011)

- Andrew Katz, who was writing for The Brooklyn Ink, said that the police "wouldn't let us get anywhere near Zuccotti." Mr. Katz said that at the corner of Broadway and Fulton Street, three blocks from the park, some police officers told him to stand on the sidewalk while others told him to stand on the street. (Stelter and Baker 2011)

- The Managing Editor for DNAInfo.com, Michael Ventura, said that one of his journalists was "doing his job and was arrested for that." (Stelter and Baker 2011)

- Lindsey Christ, a reporter for NY1, a local cable news channel, said that, as the police approached the park, they did not distinguish between protesters and members of the press. "Those 20 minutes were some of the scariest of my life," she said, adding that police officers took a New York Post reporter standing near her and "threw him in a choke-hold." (Stelter and Baker 2011)

- A writer for The Village Voice told a police officer, "I'm press!" to which the officer responded, "Not tonight." (Stelter and Baker 2011)

As I described in the opening to this article, the police power of the state erased the material base of Occupy's anti-corporate opposition, leaving the demonstrators with no physical center to develop and display alternatives to the market system. Demonstrators were forced to rally for a few hours and disperse or march a few blocks and disperse. These were very different material conditions in comparison to a self-evolving, self-recreating village camp. Without a fixed and charismatic operational base, they were forced to make their arguments with words unattached to an inchoate alternative camp. Because Occupy refused to offer itemized demands or an easily digestible agenda, their message was easily garbled and distorted by the mainstream media.

In the months after the eviction, the movement's national profile declined steadily, as did material support from the public. By January $3^{\text {rd }}$, 2012, when the Occupy General Assembly finally achieved consensus around a specific demand - a Constitutional amendment to end corporate personhood - the public had largely stopped paying attention. By the one-year anniversary of the occupation, Occupy's decision-making bodies had long since stopped meeting, their website was no longer interactive, and they had still had no central camp. Their focus on economic inequality smartly shifted to a focus on debt, whether it be student debt, consumer debt, or the debt that small nations owe to the World Bank. Off-stage now, activists still oppose economic inequality, but, without mass circulation of their discourse, they are no longer positioned in a way that would allow them to contribute to social reconstruction. 


\section{Conclusion}

In the United States, the corporate mass media typically refuses to circulate information produced by dissenting groups, thus quarantining it from mass circulation and public perception. Without a doubt, individual critics have space to publish online or in print or hand out flyers on the street, or even yell on a street corner because the U.S. Constitution formally guarantees legal rights to dissent. Oppositional groups perform isolated demonstrations and rallies, even large ones, but elites are not threatened by those actions, which are neither longterm, nor amplified, nor widely circulated, nor received meaningfully by large audiences.

In contrast, Occupy's actions in late 2011 were long-term, amplified, widely circulated, and meaningfully received by large audiences. Occupy marched to the center of high finance, denounced the nation's financial elite, and encouraged others to do the same. This is what charismatic leadership does - it acts against and for things that speak to the orientations of masses of people who can't or won't act on those orientations publicly. As a movement, Occupy put into words and actions "the essence of thousands upon thousands of bitter jokes, resentments, and outrage accumulated around kitchen tables, in small groups of workers, in beer halls, and among close companions" (Scott 1990: 226). Occupy assumed a charismatic posture, perhaps even becoming national heroes not only because their tactics were bold and clever, but because they made the first public declaration of what so many had been saying offstage without the amplification of mass media or mass movements.

On the day after the Zuccotti encampment was destroyed, Mayor Mike Bloomberg issued an official statement stating that Occupy's encampment was "an intolerable situation" and declaring that "inaction was not an option" (Halbfinger and Barbaro 2011). Bloomberg's statements ostensibly referred to problems with safety and sanitation in the park, but my analysis suggests that Occupy was intolerable to the City primarily for reasons having nothing to do with public health: Occupy's oppositional discourse had reached mass circulation and mass legitimacy and the soft means for marginalizing the movement were very weak because of the 2008 bank bailouts which were heavily biased toward the rich.

\section{References}

Bagdikian, B. H. (2004) The New Media Monopoly. Boston, Massachusetts: Beacon Press.

Baker, A., and Joseph Goldstein (2011) "Officer's Pepper-Spraying of Protesters Is Under Investigation." City Room 28 Sept. 2011. Available at: $<<$ http://cityroom.blogs.nytimes.com/2011/09/28/police-department-to-examinepepper-spray-incident $>$ [Accessed: 26 July 2013.]

Barbaro, M., and Kate Taylor (2011) "Occupy Wall Street Protesters Remain in Zuccotti Park as Cleanup Is Canceled." The New York Times 14 Oct. 2011. Available at: $<<$ http://www.nytimes.com/2011/10/15/nyregion/occupy-wall-street-protestersremain-in-zuccotti-park-as-cleanup-is-canceled.html > [Accessed: 4 Aug. 2013. ]

Bellafante, G. (2011) "Every Action Produces Overreaction." New York Times, Late Edition (East Coast) 2 Oct. 2011: MB.1. Print.

Carr, D. (2011) "Wall Street Protesters Have Ink-Stained Fingers." The New York Times 9 Oct. 2011. Available at: <<http://www.nytimes.com/2011/10/10/business/media/wallstreet-protesters-have-ink-stained-fingers-media-equation.html $>$ [Accessed: 26 July 2013.]

Croteau, D., and William Hoynes (1994) By Invitation Only: How the Media Limit Political 
Debate. Monroe, ME: Common Courage Press.

Cuozzo, Steve (2011) "Mike Is Blowing It." New York Post. 11 Nov. 2011. Available at: <<http://nypost.com/2011/11/11/mike-is-blowing-it〉> [Accessed: 6 Dec. 2013.]

Epstein, E. A. (2011). "Is Occupy Wall Street the Top 1 Percent?" Metro New York 23 Oct. 2011. Available at: <<http://www.metro.us/local/is-occupy-wall-street-the-top-1percent/tmWkjw---69jJB67op0vpw>> [Accessed: 6 Dec. 2013.]

Fairclough, N. (2006) Language and Globalization. London: Routledge.

Foderaro, L. W. (2011) "Zuccotti Park Is Privately Owned, but Open to the Public." The New York Times 13 Oct. 2011. Available at: <<http://www.nytimes.com/2011/10/14/nyregion/zuccotti-park-is-privately-ownedbut-open-to-the-public.html > [Accessed: 25 July 2013.]

Gitlin, T. "Occupy Wall Street and the Tea Party." The New York Times 8 Oct. 2011. Available at: <<http://www.nytimes.com/2011/10/09/opinion/sunday/occupy-wallstreet-and-the-tea-party.html > [Accessed: 29 July 2013.]

Gillham, P. F., Edwards, B. and Noakes, John A. (2013) "Strategic Incapacitation and the Policing of Occupy Wall Street Protests in New York City, 2011." Policing and Society 23(1): 81-102. CrossRef

Goodman, A. (2011) "Organizer Behind 'Occupy Wall Street' Has History of Anti-Jewish Writing." Commentary 13 Oct. 2011. Available at: $<<$ https://www.commentarymagazine.com/culture-civilization/occupy-wall-streetkalle-lasn >> [Accessed: 29 July 2013.]

Halbfinger, D. M., and Michael Barbaro (2011) "Jolted, Wall Street Protesters Face an Uncertain Future." The New York Times 15 Nov. 2011. Available at: << http://www.nytimes.com/2011/11/16/nyregion/ousted-wall-street-protesters-face-anuncertain-future.html > [Accessed: 4 Aug. 2013.]

Holcomb, J. (2011) “Occupy Wall Street Drives Economic Coverage." Pew Research Center's Journalism Project 9 Oct. 2011. Available at: <<http://www.journalism.org/2011/10/09/pej-news-coverage-index-october-392011〉> [Accessed: 22 Nov. 2013.]

Holcomb, J. (2011) "Biggest Week Yet for Occupy Wall Street Coverage." Pew Research Center's Journalism Project 19 Nov. 2011. Available at: $<<$ http://www.journalism.org/2011/11/19/pej-news-coverage-index-november-14202011 > [Accessed: 6 Dec. 2013.]

Ignizio, V. M. (2011) "We're Paying the Bill." New York Post 17 Oct. 2011. Available at: <<http://nypost.com/2011/10/17/were-paying-the-bill>> [Accessed: 1 Aug. 2013.

Miller, H. (2011) "Rep. Peter King Calls Occupy Wall Street Protesters 'Ragtag Mob,' "Anarchists." Huffington Post 7 Oct. 2011. Available at: <<http://www.huffingtonpost.com/2011/10/07/peter-king-occupy-wallstreet_n_1000318.html > [Accessed: 3 Aug. 2013.]

Muskal, M. (2011) "Occupy Wall Street: Most N.Y. Voters Back Protests, Poll Finds." Nation Now 17 Oct. 2011. Available at: <<http://latimesblogs.latimes.com/nationnow/2011/10/occupy-wall-street-newyorkers-quinnipiac-poll.html > [Accessed: 25 July 2013.]

“Occupy Wall Street Protesters Need to Start Living in the Real World." NY Daily News. Available at: <<http://www.nydailynews.com/opinion/occupy-wall-street-protestersstart-living-real-world-article-1.962341 > [Accessed: 29 July 2013.]

Olen, H. (2011) "For Children's Sake, Taking to the Streets." The New York Times 26 Oct. 2011. Available at: <<http://www.nytimes.com/2011/10/27/fashion/for-childrenssake-taking-to-the-streets.html > [Accessed: 25 July 2013.]

Oresmus, W. (2011) “Occupy Wall Street: Poll Shows Protests' Mainstream Popularity." 
Slate 18 Oct. 2011. Internet. [Accessed: 31 July 2013.]

Roberts, S. (2011) “A Public Servant Linked to a Protest's Home.” The New York Times 6

Oct. 2011.

Available

at:

<<http://query.nytimes.com/gst/fullpage.html?res=9C04E2DD1430F935A35753C1A 9679D8B63 > [Accessed: 6 Dec. 2013.]

Saad, L. "In U.S., Majority Still Wants Less Corporate Influence." Gallup 1 Feb. 2011. Available at: <<http://www.gallup.com/poll/145871/majority-wants-less-corporateinfluence.aspx $\gg>$ [Accessed: 1 Aug. 2013.]

Saul, J. (2011) “OWS Camp Gets Really Commie-Cal.” New York Post 31 Oct. 2011. Available at: <<http://nypost.com/2011/10/31/ows-camp-gets-really-commie-cal〉> [Accessed: 6 Dec. 2013.]

Scott, J. C. (1990) Domination and the Arts of Resistance: Hidden Transcripts. New Haven: Yale University Press.

Stelter, B. (2011) "Occupy Wall Street Puts the Coverage in the Spotlight." The New York Times 20 Nov. 2011. Available at: <<http://www.nytimes.com/2011/11/21/business/media/occupy-wall-street-puts-thecoverage-in-the-spotlight.html > [Accessed: 7 Aug. 2013.]

Stille, A. (2011) "Social Inequality and the New Elite." The New York Times 22 Oct. 2011. Available at: <<http://www.nytimes.com/2011/10/23/opinion/sunday/socialinequality-and-the-new-elite.html $>$ [Accessed: 6 Dec. 2013.]

"Well Played, Mr. Mayor." New York Post 16 Nov. 2011. Available at: <<http://nypost.com/2011/11/16/well-played-mr-mayor〉> [Accessed: 29 July 2013.]

West, C. (2012) "After Winter Must Come Spring: An Evening with Michael Moore and Cornell West." Hunter College.

Zeleny, J., and Megan Thee-Brenan (2011) "New Poll Finds a Deep Distrust of Government." The New York Times 25 Oct. 2011. Available at: <<http://www.nytimes.com/2011/10/26/us/politics/poll-finds-anxiety-on-theeconomy-fuels-volatility-in-the-2012-race.html >> [Accessed: 08 Nov. 2015.] 